\title{
EFEKTIVITAS MEDIA PEMBELAJARAN INTERAKTIF BERBANTUAN WEB DALAM MENGEMBANGKAN KEMAMPUAN BERPIKIR KREATIF
}

\author{
Andini Dwi Rachmawati ${ }^{1}$, Baiduri ${ }^{2}$, Moh. Mahfud Effendi ${ }^{3}$ \\ ${ }^{1,2,3}$ Pendidikan Matematika, Universitas Muhammadiyah Malang, Malang, Indonesia \\ E-mail: $\quad$ andinidwirachmawati@gmail.com ${ }^{1)}$ \\ baiduriumm@gmail.com $^{2)}$ \\ mahfud@umm.ac.id ${ }^{3}$
}

Received 04 August 2020; Received in revised form 08 September 2020; Accepted 11 September 2020

\begin{abstract}
Abstrak
Penelitian ini bertujuan untuk mendeskripsikan keefektifan dari penggunaan media pembelajaran interaktif berbantuan web dalam mengembangkan kemampuan berpikir kreatif. Populasi penelitian ini adalah peserta didik kelas VIII SMPN 1 Kemlagi tahun ajaran 2019/2020 semeserta genap. Jumlah peserta didik sebanyak 32 orang. Penelitian ini termasuk penelitian pra-eksperimental menggunakan One Group Pretest-Posttest Design. Pembelajaran menggunakan media pembelajaran interaktif berbantuan web dilaksanakan dalam enam kali tatap muka dan satu kali pemberian tes akhir (post-test). Instrumen yang digunakan dalam penelitian ini adalah angket respon peserta didik terhadap penggunaan media pembelajaran interaktif berbantuan web dan tes kemampuan berpikir kreatif. Hasil penelitian menunjukkan bahwa keefektifan penggunaan media pembelajaran interaktif berbantuan web dari nilai rata - rata angket respon peserta didik mencapai 88,36\% dengan kategori sangat baik. Perhitungan $N$ gain adalah 0,51 dengan kategori sedang. Uji Paired Sample T-test memperoleh hasil tingkat signifikansi $0,00<0,05$ (efektif). Hal ini menunjukkan bahwa antara pre-test sebelum menggunakan media pembelajaran interaktif dan post-test setelah menggunakan media pembelajaran interaktif mengalami perbedaan yang signifikan Berdasarkan hasil beberapa uji disimpulkan bahwa media pembelajaran interaktif berbantuan web efektif dalam mengembangkan kemampuan berpikir kreatif.
\end{abstract}

Kata kunci: efektif, kemampuan berpikir kreatif, media pembelajaran interaktif berbantuan web

\begin{abstract}
This study aims to describe the effectiveness of the use of web-assisted interactive learning media in developing creative thinking skills. The population of this study were students of class VIII SMPN 1 Kemlagi in the 2019/2020 academic year as well as even. The number of students was 32 people. This research includes pre-experimental research using the One Group Pretest-Posttest Design. Learning using web-assisted interactive learning media is carried out in six face-to-face and one post-test. The instrument used in this study was a student response questionnaire to the use of web-assisted interactive learning media and tests of creative thinking skills. The results showed that the effectiveness of the use of web-assisted interactive learning media from the average value of the students' questionnaire responses reached $88.36 \%$ in the very good category. The $N$-gain calculation is 0.51 in the medium category. The Paired Sample T-test resulted in a significance level of $0.00<0.05$ (effective). This shows that between the pre-test before using interactive learning media and the post-test after using interactive learning media experiences a significant difference. Based on the results of several tests it is concluded that webassisted interactive learning media is effective in developing creative thinking skills.
\end{abstract}

Keywords: effective, creative thinking skills, web-assisted interactive learning media. 
DOI: https://doi.org/10.24127/ajpm.v9i3.3014

\section{PENDAHULUAN}

Pembelajaran matematika di setiap jenjang dirancang sedemikian rupa agar dapat mencapai tujuan pembelajaran yang telah disusun (Supriadi, 2015). Setelah tujuan pembelajaran matematika tercapai, peserta didik diharapkan mampu menghadapi era revolusi industri (Bagherzadeh, Keshtiaray, \& Assareh, 2017). Keterampilan yang dibutuhkan untuk menghadapi era revolusi industri adalah berpikir kreatif (Astutik \& Prahani, 2018).

Kemampuan berpikir kreatif adalah kemandirian berpendapat secara logis untuk mencari solusi permasalahan matematika berdasarkan konsep dan prosedur (Hanipah, Yuliani, \& Maya, 2018; Kadir, Lucyana, 2017). Peserta didik mampu menemukan solusi masalah matematika dengan sudut pandang yang berbeda - beda (Munahefi, Waluya, \& Rochmad, 2018). Perbedaan sudut pandang karena adanya perbedaan peserta didik dalam menerima rangsangan guru saat proses pembelajaran (Maharani, 2017). Terdapat beberapa indikator berpikir kreatif peserta didik yaitu (1) kelancaran dimana peserta didik dapat menghasilkan gagasan dalam jumlah banyak; (2) keluwesan, pada indikator ini peserta didik memberikan cara berbeda untuk menyelesaikan permasalahan dan mampu menyelesaikan masalah dengan sudut pandang yang berbeda; (3) keaslian dalam indikator tersebut peserta didik mampu menganalisis sendiri permasalahannya dengan cara baru; (4) keterperincian, peserta didik memberikan jawaban secara rinci dan detail, prosedur pengerjaan soal ditulis dengan jelas dan benar (Sowden, Pringle, \& Gabora, 2015; Bacanli; Puspitasari, In'am, \& Syaifuddin, 2019).
Berapa penelitian sebelumnya seperti Fitri, Sibuea, \& Handayani (2019) ; Hasanah (2019); Rahmawati, Buchori, \& Endahwuri (2016); Rizal, Rahmat, \& Rizal (2016); Syukuria (2017) telah melakukan penelitian mengukur tingkat kefektifan media pembelajaran interaktif. Namun, beberapa penelitian di atas belum ada yang meneliti efektifitas media pembelajaran interaktif berbantuan web yang mampu mengembangkan kemampuan berpikir kreatif.

Hasil pengamatan ketika kegiatan belajar mengajar di SMPN 1 Kemlagi bahwa pembelajaran berlangsung secara konvensional. Pembelajaran konvensional tersebut berjalan juga tanpa adanya penggunaan media pembelajaran. Pembelajaran matematika yang kurang bervariasi akan mempersulit perkembangan kemampuan berpikir kreatif. Kemampuan berpikir kreatif peserta didik dalam menyelesaikan tes masih sangat rendah. Jawaban yang diberikan cenderung monoton dan kurang bervariasi. Hal itu sejalan dengan penelitian yang dilakukan oleh Puspitasari, In'am, \& Syaifuddin (2019); Putra, Akhdiyat, Setiany, \& Andiarani (2018) bahwa sebagian besar peserta didik dalam memberikan jawaban kurang sistematis, terperinci.

Berdasarkan latar belakang tersebut, tujuan penelitian ini adalah untuk mengetahui efektifitas media pembelajaran dalam mengembangkan kemampuan berpikir kreatif.

\section{METODE PENELITIAN}

Jenis penelitian yang digunakan dalam penelitian ini adalah penelitian kuantitatif pra-eksperimental dengan menggunakan one group pretestposttest design (Sugiyono, 2017). 
DOI: https://doi.org/10.24127/ajpm.v9i3.3014

Desain yang akan digunakan dalam penelitian ini dapat dilihat pada Tabel 1 .

Tabel 1. Desain penelitian one group pretest-posttest design

\begin{tabular}{ccc}
\hline Pre-test & Treatment & Post-test \\
\hline $\mathrm{O}_{1}$ & $\mathrm{X}$ & $\mathrm{O}_{2}$ \\
\hline
\end{tabular}

Penelitian ini dilakukan di SMP Negeri 1 Kemlagi pada semester genap tahun ajaran 2019/2020. Pembelajaran menggunakan media pembelajaran interaktif berbantuan web dilaksanakan dalam enam kali tatap muka dan satu kali pemberian tes akhir (post-test).

Populasi penelitian ini adalah peserta didik kelas VIII SMPN 1 Kemlagi tahun ajaran 2019/2020 semester genap. Jumlah sample yang dipilih sebanyak 32 orang. Teknik pengambilan sampel yaitu purposive sampling yaitu penentuan sampel dengan pertimbangan tertentu. Pengambilan sampel juga sesuai dengan pertimbangan guru matematika yang mengajar di sekolah tersebut. Media pembelajaran interaktif berbantuan web ini berisikan materi persamaan garis lurus, di mana soal evaluasi disusun sesuai dengan indikator kemampuan berpikir kreatif peserta didik SMPN 1 Kemlagi, Mojokerto.

Teknik pengumpulan data yang digunakan pada penelitian ini adalah teknik tes dan non tes. Teknik tes digunakan untuk mengukur kemampuan berpikir kreatif matematis peserta didik. Sedangkan teknik non tes digunakan untuk mengukur respon peserta didik terhadap penggunaan media pembelajaran interaktif berbantuan web.

Instrumen kemampuan berpikir kreatif berupa soal uraian yang diadaptasi dari soal UN sebanyak satu soal. Instrumen respon berupa angket tertutup dengan skala Like dengan empat pilihan sebanyak 15 item, diadaptasi Sanusi, Suprapto, \& Apriandi (2015).

Analisis data yang dilakukan dalam penelitian ini antara lain analisis deskriptif dan analisis inferensial meliputi uji $N$-gain, uji normalitas, uji homogenitas, dan uji T-test (Paired Samples T-test).

Analisis deskriptif untuk mendeskripsikan hasil dari proses pembelajaran berdasarkan data yang diperoleh. Skor dari angket respon penggunaan media pembelajaran interaktif berbantuan web dengan menggunakan statistik deskriptif. Berikut ini adalah rumus yang digunakan untuk mengkonversi :

Nilai $=\frac{\text { jumlah nilai yang diperoleh }}{\text { nilai maksimal }} \times 100 \%$

Persentase skor yang diperoleh akan di konversikan menjadi nilai kualitatif dengan empat kriteria. Pedoman klasifikasi penilaian terdapat pada Tabel 2.

Tabel 2. Kriteria kualitatif tes berpikir kreatif.

\begin{tabular}{cc}
\hline Interval Nilai & Kriteria \\
\hline $81,25 \%<x \leq 100 \%$ & Sangat Baik \\
$62,50 \%<x \leq 81,25 \%$ & Baik \\
$43,75 \%<x \leq 62,50 \%$ & Kurang Baik \\
$25 \%<x \leq 43,75 \%$ & Tidak Baik \\
\hline
\end{tabular}

Selanjutnya analisis inferensial dilakukan dengan beberapa uji. Tahap pertama, peserta didik diberikan tes awal. Tujuan diberikannaya tes awal (pretest) adalah untuk melihat tingkat awal kemampuan berpikir kreatif peserta didik sebelum menerapkan media pembelajaran interaktif 
berbantuan web. Untuk mengetahui tingkat kefeketifan media pembelajaran interaktif berbantuan web dapat dilihat melaui hasil pretest dan posttest yang kemudian dianalisis menggunakan $\mathrm{N}$ gain dan uji $T$-test media pembelajaran berbasis web. Beberapa hipotesis yang disusun dalam penelitian ini adalah sebagai berikut:

$\mathrm{H}_{0}$ : tidak terdapat perbedaan signifikan sebelum dan setelah menerapkan media pembelajaran interaktif berbantuan web $\mathrm{H}_{1}$ : ada perbedaan signifikan sebelum dan setelah menerapkan media pembelajaran interaktif berbantuan web

Tahap kedua, melakukan uji $N$ gain untuk mengetahui peningkatan kemampuan berpikir kreatif sebelum dan setelah menggunakan media pembelajaran interaktif berbantuan web. Kriteria keefektifan media pembelajaran interaktif berbantuan web disesuaikan dengan kriteria $\mathrm{N}$-gain oleh Meltzer (2002) seperti pada Tabel 3.

Tabel 3. Kriteria $N$-gain

\begin{tabular}{cl}
\hline$N$-gain & Kriteria \\
\hline $0,7 \leq N$-gain $\leq 1$ & Tinggi \\
$0,3 \leq N$-gain $\leq 0,7$ & Sedang \\
$N$-gain $<0,3$ & Rendah \\
\hline
\end{tabular}

Tahap ketiga, uji normalitas dan homogenitas. Hasil yang diperoleh digunakan sebagai uji prasyarat Paired Sample T-test melaui uji KolmogorovSmirnov. Begitu pun pada hasil Lavene Test digunakan sebagai uji prasyarat Paired Sample T-test Paired melalui uji Lavene Test.

Tahap keempat, melalukan uji Paired Sample T-test. Uji tersebut dilakukan dengan tujuan untuk mengetahui ada tidaknya perubahan $\mathrm{n}$ nilai rata - rata yang signifikan sebelum dan setelah menggunakan media pembelajaran interaktif berbantuan web. Ketiga uji tersebut dilakukan dengan menggunakan bantuan IBM SPSS 20 .

\section{HASIL DAN PEMBAHASAN}

Pada penelitian ini, data yang analisis menggunakan deskripsi data dan analisis inferensial. Analisis deskripsi data menggunakan angket respon peserta didik terhadap penggunaan media pembelajaran interaktif berbantuan web. Sedangkan analisis inferensial menggunakan kemampuan berpikir kreatif.

1. Respon Peserta Didik

Angket yang diberikan terdiri dari 15 butir pertanyaan. Respon peserta didik distribusikan kepada seluruh sampel penelitian setelah diberikan treatment pembelajaran. Hasil angket respon peserta didik akan disajikan pada Tabel 4.

Tabel 4. Respon peserta didik SMPN 1 Kemlagi terhadap penggunaan media pembelajaran interaktif berbantuan web

\begin{tabular}{lll}
\hline No. & \multicolumn{1}{c}{ Aspek } & $\begin{array}{c}\text { Skor } \\
(\mathbf{\%})\end{array}$ \\
\hline 1. & Penyampaian Materi & 89,32 \\
2. & Berpikir Kreatif & 88,48 \\
3. & Kebermanfaatan & 87,37 \\
4. & Ketertarikan Media & 88,28 \\
\hline & Rata - rata & 88,36 \\
\hline
\end{tabular}

Berdasarkan Tabel 4 skor yang diperoleh untuk hasil respon peserta terhadap penggunaan media pembelajaran interaktif berbantuan web yang terbagi dalam empat aspek. Aspek pertama yaitu aspek penyampaian materi yang memperoleh skor tertinggi. Hal itu disebabkan karena media pembelajaran interaktif berbantuan web berisi sebuah simulasi yang nantinya 
mampu mempermudah peserta didik dalam memahami suatu konsep. Materi pada menu simulasi yang disajikan terstruktur dengan baik dan memiliki keterkaitan antara satu dengan yang lainnya.

Aspek kedua yaitu aspek berpikir kreatif. Pada aspek kedua ini, setelah menggunakan media pembelajaran interaktif dapat mengembangkan kemampuan berpikir kreatif. Perkembangan yang dialami peserta didik dapat ditandai dengan adanya berbagai macam ide yang bervariasi ketika menyelesaikan suatu masalah. Tidak hanya itu saja, melalui media pembelajaran interaktif ini peserta didik juga dapat menemukan jawabannya sendiri. Media pembelajaran interaktif berbantuan web juga mampu membantu peserta didik dalam menjawab permasalahan secara rinci.

Aspek kebermanfaatan merupakan aspek yang ketiga. Skor yang diperoleh merupakan skor terendah. Beberapa peserta didik mengalami kesulitan dalam menarik kesimpulan, menemukan konsep secara mandiri. Proses pembelajaran yang berlangsung secara konvensional membuat peserta didik merasa kesulitan dalam mengoperasikan media pembelajaran interaktif berbantuan web. Meskipun demikian, dengan media pembelajaran interaktif berbantuan web dapat membuat peserta didik terampil dalam menyelesaikan masalah.

Selanjutnya adalah aspek ketertarikan terhadap media. Media pembelajaran interaktif dapat menarik perhatian peserta didik. Perhatian peserta didik dapat terpusatkan ketika proses pembelajaran berlangsung. Karena simulasi yang diberikan akan memberikan arahan peserta didik dalam menemukan suatu konsep.

\section{Kemampuan Berpikir Kreatif}

Untuk mengetahui tingkat kefektifan media pembelajaran interaktif berbantuan web dapat dilihat melalui beberapa hasil uji kemampuan berpikir kreatif. Pertama, melakukan uji deskriptif kuantitatif. Uji deskriptif ini menggunakan data tes awal dan tes akhir penggunaan media pembelajaran interaktif berbantuan web. Hasil uji tersebut dapat dilihat dalam Tabel 5.

Tabel 5. Deskriptif hasil pre-test dan post-test

\begin{tabular}{cccc}
\hline $\begin{array}{c}\text { Jenis } \\
\text { Data }\end{array}$ & Min & Max & $\begin{array}{c}\text { Rata - } \\
\text { rata }\end{array}$ \\
\hline Pre-test & 69 & 73 & 71,25 \\
Post-test & 84 & 88 & 86,00 \\
\hline
\end{tabular}

Berdasarkan Tabel 5 hasil pre-test dan post-test mengalami peningkatan. Hal tersebut ditandai adanya perubahan nilai rata - rata yang signifikan.

Kedua adalah menghitung $N$-gain dari pretest-posttest setiap peserta didik dan diperoleh hasil dengan beberapa kriteria yaitu rendah, sedang, dan tinggi sesuai dengan Tabel 6.

Tabel 6. Kriteria $N$-gain nilai pret-test dan post-test

\begin{tabular}{ccc}
\hline Data & $\begin{array}{c}\text { Rata -rata } \\
N \text {-gain }\end{array}$ & Kategori \\
\hline $\begin{array}{c}\text { Nilai pre- } \\
\text { test } \text { dan } \\
\text { post-test }\end{array}$ & 0,51 & Sedang \\
\hline
\end{tabular}

Tabel 6 menampilkan hasil dari rata-rata $N$-gain yaitu sebesar 0,51 . Hal ini menyatakan bahwa efektifitas media pembelajaran interaktif yang dikembangkan termasuk dalam kategori sedang. Hal tersebut terjadi karena sebagian peserta didik kurang 
memperhatikan materi apa yang disampaikan oleh guru. Peserta didik juga hanya mengerjakan apa yang ada di soal evaluasi tanpa memahami simulasi yang diberikan.

Ketiga, melakukan uji normalitas Kolmogorov Smirnov. Data yang digunakan untuk uji normalitas Kolmogorov Smirnov adalah rata - rata nilai pretest, posttest dan $N$-gain Hasil uji dapat dilihat pada Tabel 7 .

Tabel 7. Uji Normalitas Kolmogorov Smirnov pretest, posttest, dan $N$-gain

\begin{tabular}{cll}
\hline No & Jenis Data & Sig* \\
\hline 1. & Pre-test & 0,999 \\
2. & Post-test & 0,995 \\
3. & $N$-gain & 0,932 \\
\hline
\end{tabular}

*=signifikansi level 0,05

Berdasarkan hasil uji pada Tabel 7 beberapa data seperti pre-test dan posttest berdistribusi normal.

Keempat, melakukan uji homogenitas menggunakan Lavene test untuk mengatahui apakah data yang diperoleh homegen atau tidak. Hasil Lavene test dapat dilihat pada Tabel 8.

Tabel 8. Uji homogenitas pre-test dan post-test

\begin{tabular}{lccc}
\hline \multicolumn{1}{c}{ Jenis } & Jenis Uji & Sig* & Ket \\
Data & Homogenitas & & \\
\hline $\begin{array}{l}\text { Hasil } \\
\text { pre-test } \\
\text { dan }\end{array}$ & Lavene Test & 0,66 & Homogen \\
post-test & & & \\
\hline
\end{tabular}

Berdasarkan Tabel 8 hasil uji homogenitas dengan Lavene test hasil pretest dan posttest dapat dinyatakan data homogen.

Kelima, melakukan uji Paired Sample T-Test. Uji Paired Sample T-
Test dilakukan dengan tujuan untuk melihat keefektifan penggunaan media ineteraktif apakah apakah mampu mengembangkan kemampuan berpikir kreatif. Selain itu uji Paired Sample TTest juga akan menunjukkan perbedaan nyata sebelum dan sesudah menerapkan media pembelajaran interaktif berbantuan web. Hasil uji Paired Sample T-Test dapat dilihat pada Tabel 9.

Tabel 9. Uji paired sample t-test pretest dan post-test

\begin{tabular}{cccc}
\hline Uraian & Std. Dev & t & Sig* \\
\hline $\begin{array}{c}\text { Pre-test } \text { dan } \\
\text { post-test }\end{array}$ & 1,500 & $-19,667$ & 0,000 \\
\hline
\end{tabular}

Berdasarkan Tabel 9 bahwa $\mathrm{H}_{0}$ ditolak maka $\mathrm{H}_{1}$ diterima, karena Sig. $0,000<0,05$. Hal ini menunjukkan bahwa antara pre-test sebelum menggunakan media pembelajaran interaktif dan post-test setelah menggunakan media pembelajaran interaktif mengalami perbedaan yang signifikan

Dari beberapa hasil yang diperoleh bahwa media pembelajaran interaktif berbantuan web dalam mengembangkan kemampuan berpikir kreatif teruji keefektifan dengan katagori sedang. Sesuai dengan kategori yang telah ditentukan sebelumnya maka media pembelajaran interaktif dapat digunakan sebagai media ajar dengan materi persamaan garis lurus. Hasil penelitian ini sejalan dengan penelitian Novianti, Utomo, \& Dintari (2019) yang menyatakan bahwa media pembelajaran berbasis web teruji efektif dan layak sebagai media ajar. Media pembelajaran interaktif juga mampu mengembangkan kemampuan berpikir kreatif sesuai yang dikemukakan oleh Selvy, Ikhsan, Johar, \& Saminan (2020). 
DOI: https://doi.org/10.24127/ajpm.v9i3.3014

Faktor penyebab keefektifan penggunaan media pembelajaran interaktif berbantuan web yaitu pertama, media pembelajaran interaktif berbantuan web telah melalui proses validasi. Media pembelajaran interaktif berbantuan web divalidasi oleh beberapa ahli yaitu media, materi, dan web. Kemudian media pembelajaran interaktif dikatakan cukup valid, praktis, dan dapat mengembangkan kemampuan berpikir kreatif ketika usai divalidasi. Hal itu juga sejalan dengan penelitian yang dilakukan oleh Arumsarie, Kusumaningsih, \& Sutrisno (2018).

Media pembelajaran interaktif terdiri dari beberapa menu antara lain halaman beranda (Gambar 1), peta konsep, standart isi, materi, simulasi kuis, evaluasi dan profil.

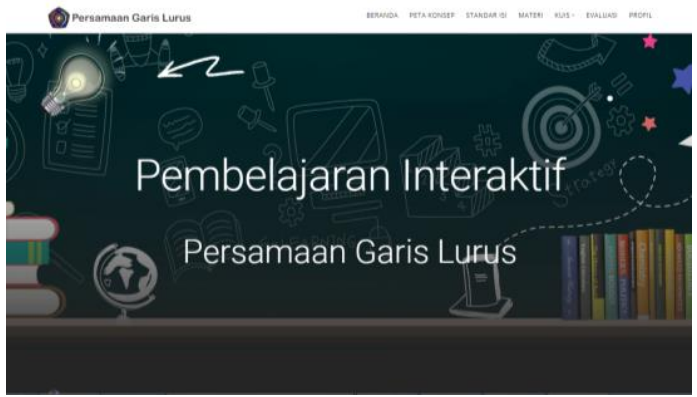

Gambar 1. Menu beranda pada media interaktif berbantuan web

Menu kedua adalah peta konsep media pembelajaran interaktif yang memberikan gambaran umum materi persamaan garis lurus yang akan dipahami. Tampilan pada menu peta konsep disajikan pada Gambar 2.

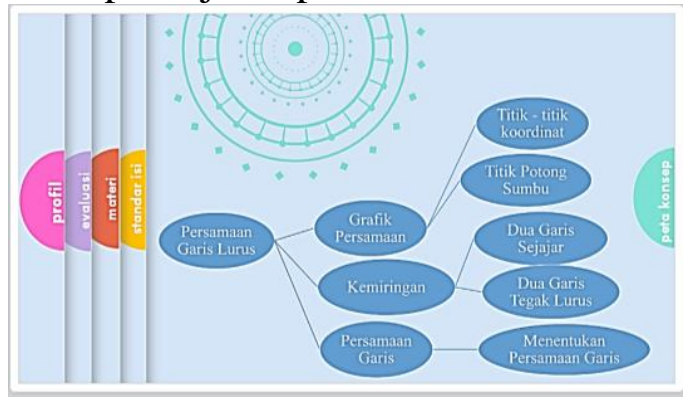

Gambar 2. Menu peta konsep pada media interaktif berbantuan web
Menu ketiga (Gambar 3) adalah menu standar isi. Isi dari menu standar isi tentang indikator yang ingin dicapai pada materi persamaan garis lurus

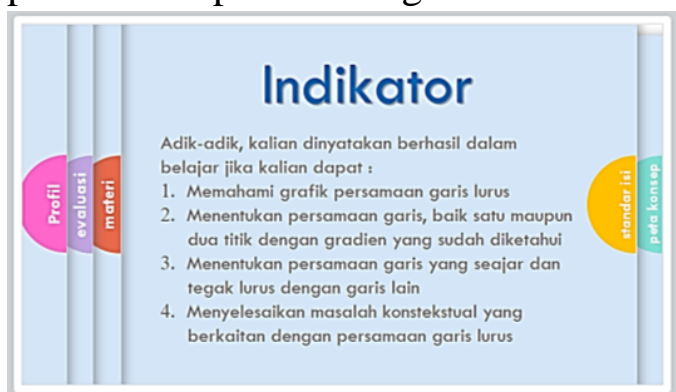

Gambar 3. Menu Standart Isi pada Media Interaktif Berbantuan Web

Menu keempat (Gambar 4) adalah menu materi. Pada menu materi terdapat beberapa prolog, kuis, dan simulasi dengan bantuan software geogebra yang nantinya dapat membantu peserta didik dalam menemukan sebuah konsep.

Menu kelima (Gambar 5) adalah menu evaluasi. Menu evaluasi merupakan menu yang berisi satu soal. Soal tersebut disusun sesuai dengan indikator kemampuan berkreatif. Melalui soal itu, dapat melihat perkembangan kemampuan berpikir kreatif sebelum dan sesudah menggunakan media pembelajaran interaktif.

Selanjutnya adalah menu evaluasi (Gambar 6). Terdapat beberapa slide dalam menu evaluasi yaitu pendidikan, filosofi pembuat media pembelajaran interaktif berbantuan web.

Menu terakhir (Gambar 7) adalah menu angket respon peserta didik terhadap media pembelajaran interaktif berbantuan web. Angket respon ini dibuat dengan bantuan google form. semua menu yang ditampilkan pada media yang dikembangkan dirancang sedemikian rupa untuk menarik minat calon pengguna (subjek penelitian). 
DOI: https://doi.org/10.24127/ajpm.v9i3.3014

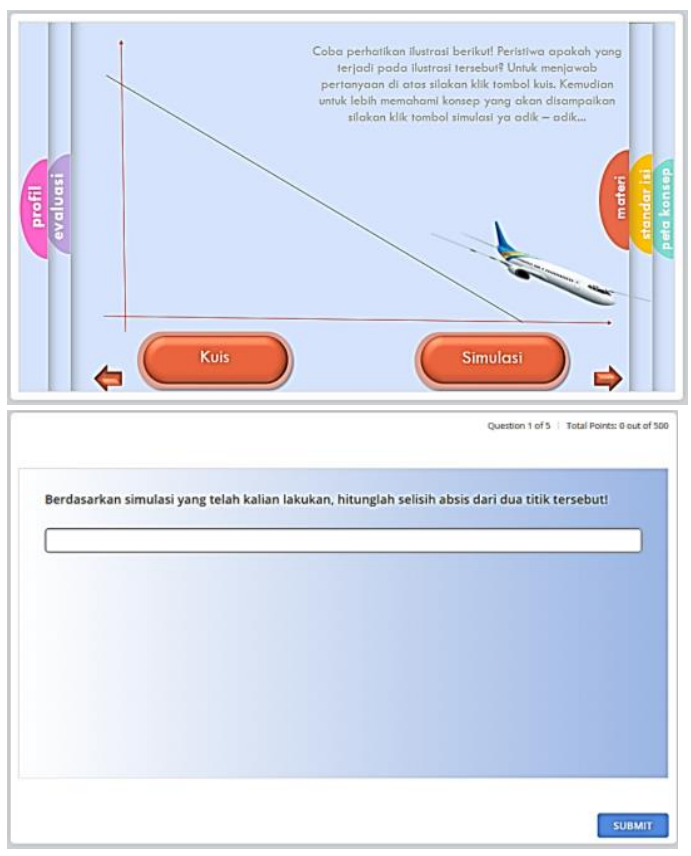

Gambar 4. Menu materi pada media interaktif berbantuan web

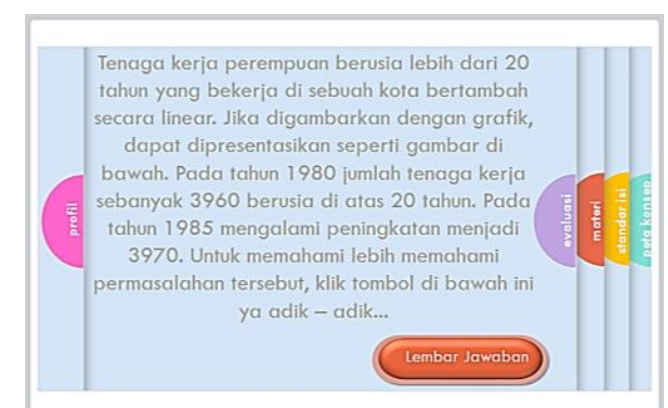

Gambar 5. Menu profil pada media interaktif berbantuan web

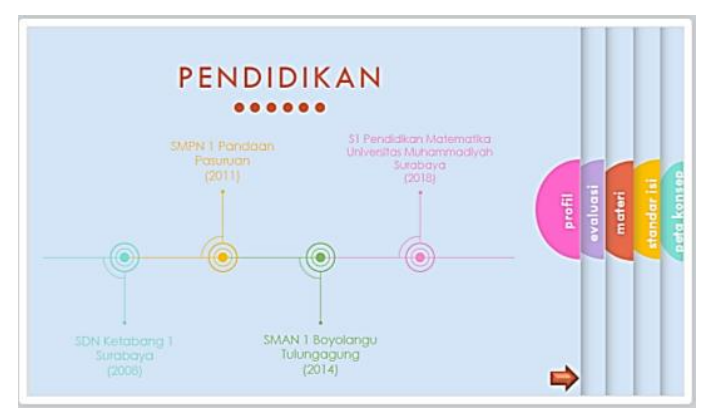

Gambar 6. Menu profil pada media interaktif berbantuan web

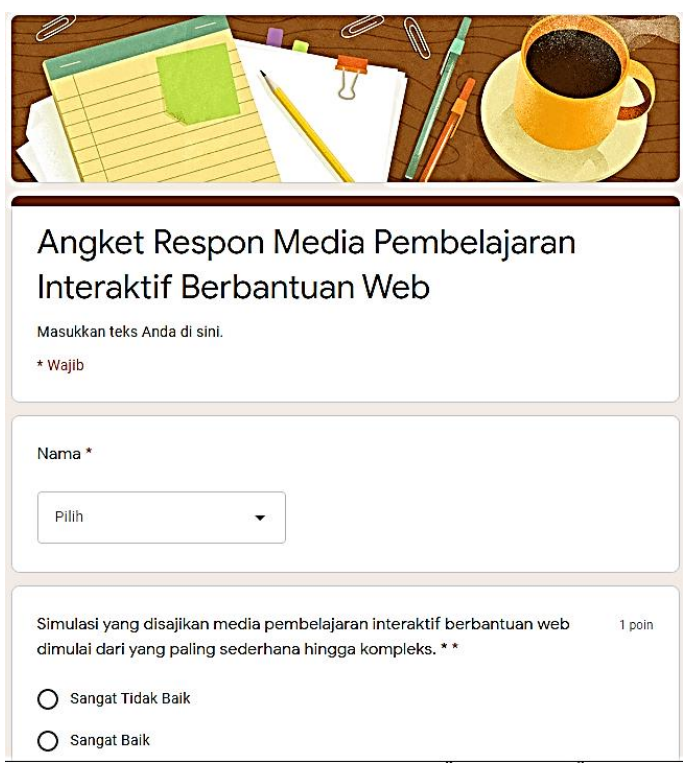

Gambar 7. Menu angket respon pada media interaktif berbantuan web

Kedua, pembuatan media pembelajaran interaktif berbantuan web disertai dengan beberapa simulasi dan permasalahan kontekstual dengan bahasa yang mudah dipahami. Sehingga peserta didik akan lebih mudah dalam mengembangkan kemampuan bepikir kreatif sebagaimana respon peserta didik melalui angket. Hal itu juga sesuai dengan penelitian Talakua \& Sesca Elly (2020) yang menyatakan bahwa pembelajaran dengan media interaktif berbantuan web mampu mengembangkan kemampuan berpikir kreatif. Saputra (2017) yang menyatakan bahwa media interaktif berbantuan web yang dikombinasikan dengan software geogebra juga mampu mengembangkan kemampuan berpikir kreatif.

Media pembelajaran interaktif berbantuan juga memiliki peran yang cukup besar bagi proses pembelajaran. Priyambodo, Wiyarsi, \& Sari (2012) menyatakan bahwa media pembelajaran interaktif berbantuan web dapat digunakan sebagai perantara. Sehingga mampu meningkatkan keterlibatan peserta didik dan menerapkan strategi 
belajar yang baru. Strategi belajar yang disusun juga disesuaikan dengan tujuan pembelajaran dan pembuatan media pembelajaran interaktif berbantuan web. Desaian yang dibuat dalam media pembelajaran interaktif berbantuan web disusun secara khusus agar terjadi interaksi antar peserta didik. Selain itu adanya interaksi peserta didik dengan komputer yang dapat menghasilkan sebuah respon. Respon yang dihasilkan digunakan sebagai landasan peserta didik dalam memperkuat daya ingat.

\section{KESIMPULAN DAN SARAN}

Berdasarkan pembahasan hasil penelitian dapat dijawab dari rumusan masalah yang telah dilakukan mengenai efektifitas media pembelajaran interaktif berbantuan web dalam mengembangkan kemampuan berpikir kreatif dapat disimpulkan dalam beberapa hal. Pertama, hasil analisis respon siswa dapat diperoleh untuk seluruh pertanyaan mencapai skor rata rata 88,36 dengan kategori sangat baik. Peserta didik memberikan respon positif terhadap pengunaan media pembelajaran interaktif. Sehingga media pembelajaran interaktif berbantuan web materi persamaan garis telah efektif dan dapat digunakan dalam proses pembelajaran. Kedua, hasil antara pretest sebelum menggunakan media pembelajaran interaktif dan post-test setelah menggunakan media pembelajaran interaktif mengalami perbedaan yang signifikan. Meskipun tes berpikir kreatif peserta didik termasuk dalam kategori sedang dalam uji $N$-gain, media pembelajaran interaktif berbantuan web memiliki kelebihan yaitu mampu mengembangkan kemampuan berpikir kreatif.

\section{DAFTAR PUSTAKA}

Arumsarie, R. A., Kusumaningsih, W., \& Sutrisno. (2018). Pengembangan Aplikasi Mobile Learning Sebagai Media Pembelajaran Untuk Meningkatkan Kemampuan Berpikir Kreatif Siswa Pada Materi Trigonometri. Media Pendidikan Matematika, 12(1), 65-75.

Astutik, S., \& Prahani, B. K. (2018). The Practicality and Effectiveness of Collaborative Creativity Learning (CCL) Model by Using PhET Simulation to Increase Students' Scientific Creativity. International Journal of Instruction, 11(4), 409-424.

Bagherzadeh, Z., Keshtiaray, N., \& Assareh, A. (2017). A brief view of the evolution of technology and engineering education. Eurasia Journal of Mathematics, Science and Technology Education, 13(10), 6749-6760.

Fitri, M., Sibuea, L., \& Handayani, M. (2019). Efektivitas Pengembangan Media Pembelajaran Monopoli Matematika ( Monotika) Siswa. Jurnal Education and Development, 7(4), 41-48.

Hanipah, N., Yuliani, A., \& Maya, R. (2018). Analisis Kemampuan Berpikir Kreatif Matematis Siswa MTs Pada Materi Lingkaran. AKSIOMA: Jurnal Program Studi Pendidikan Matematika, 7(1).

Hasanah, R. U. (2019). Efektivitas Multimedia Interaktif Untuk Meningkatkan Kemampuan Penalaran Geometris Siswa Kelas VIII. Axiom, VIII(1), 50-63. 
Kadir, Lucyana, G. S. (2017). the Implementation of Open-Inquiry Approach To Improve Students , Learning Activities, Responses , and. Journal on Mathematics Education, 8(1), 103-114.

Maharani, A. (2017). Analisis Pengembangan Soal Tes Evaluasi Matematika Berbasis Kemampuan Berpikir Kreatif Untuk Siswa SMK pad Materi Geometri. AKSIOMA: Jurnal Program Studi Pendidikan Matematika, 6(3).

Meltzer, D. E. (2002). The relationship between mathematics preparation and conceptual learning gains in physics: A possible "hidden variable" in diagnostic pretest scores. American Journal of Physics, 70(12), 1259-1268.

Munahefi, D. N., Waluya, S. B., \& Rochmad. (2018). Analysis of Creative Mathematic Thinking Ability in Problem Based Learning Model Based on Self- Regulation Learning. Journal of Physics: Conference Series, 983(1), 1-5.

Novianti, V., Utomo, D. P., \& Dintari, M. (2019). Development of Web Based Interactive Learning Media on Lines and Angles Material in 7th grade of Junior High School. Mathematics Education Journals, 3(1), 62-71.

Priyambodo, E., Wiyarsi, A., \& Sari, R. L. P. (2012). Pengaruh Media Pembelajaran Interaktif Berbasis Web Terhadap Motivasi Belajar Mahasiswa. Pengaruh Media Pembelajaran Interaktif Berbasis Web Terhadap Motivasi Belajar Mahasiswa, 42(2), 99-109.
Puspitasari, L., In'am, A., \& Syaifuddin, M. (2019). Analysis of Students ' Creative Thinking in Solving Arithmetic Problems. International Electronic Journal of Mathematics Education, 14(1), 4960.

Putra, H. D., Akhdiyat, A. M., Setiany, E. P., \& Andiarani, M. (2018). Kemampuan Berpikir Kreatif Matematik Siswa SMP di Cimahi. Kreano, Jurnal Matematika Kreatif-Inovatif, 9(1), 47-53.

Rahmawati, N. D., Buchori, A., \& Endahwuri, D. (2016). Efektivitas Penggunaan Multimedia Interaktif dengan Pendekatan Matematika Realistik pada Mata Kuliah Matematika SMA. JKPM, 3(2), 27-36.

Rizal, A. S., Rahmat, M., \& Rizal, A. S. (2016). Efektivitas Multimedia Interaktif Flash Pada Pembelajaran Pendidikan Agama Islam Di Sekolah. Jurnal Pendidikan Agama Islam-Ta'lim, 14(2), 165-183.

Sanusi, Suprapto, E., \& Apriandi, D. (2015). Pengembangan Multimedia Interaktif Sebagai Media Pembelajaran Pada Pokok Bahasan Dimensi Tiga Di Sekolah Menengah Atas. Ilmiah Pendidikan Matematika, 3(2), 398-416.

Saputra, P. R. (2017). Pembelajaran Geometri Berbantuan Geogebra dan Cabri Ditinjau dari Prestasi Belajar, Berpikir Kreatif dan SelfEfficacy. PYTHAGORAS: Jurnal Pendidikan Matematika, 11(1), 59. 
Selvy, Y., Ikhsan, M., Johar, R., \& Saminan. (2020). Improving students' mathematical creative thinking and motivation through GeoGebra assisted problem based learning. Journal of Physics: Conference Series, 1460(1).

Sowden, P. T., Pringle, A., \& Gabora, L. (2015). The shifting sands of creative thinking: Connections to dual-process theory. Thinking and Reasoning, 21(1), 40-60.

Sugianto, Hayati, F., \& Junitasari. (2018). Analisis Kemampuan Berpikir Kreatif Matematis Siswa SMP Pada Materi Persamaan Garis Lurus. Pendidikan Tambunsai, 2(6), 1678-1686.

Sugiyono. (2017). Metode Penelitian Pendidikan Pendekatan Kuantitatif, Kualitatif, dan $R \& D$. Bandung: Alfabeta.

Supriadi, N. (2015). Mengembangkan Kemampuan Koneksi Matematis Melalui Buku Ajar Elektronik Interaktif (BAEI) yang Terintegrasi Nilai-Nilai Keislaman. Al-Jabar: Jurnal Pendidikan Matematika, 6(1), 63-73.
Syukuria, A. (2017). Efektivitas Penggunaan Multimedia Interaktif Pada Materi Dimensi Tiga. AlKhwarizmi: Jurnal Pendidikan Dan Pembelajaran Matematika, 6(1), 51-66.

Talakua, C., \& Sesca Elly, S. (2020). Pengaruh Penggunaan Media Pembelajaran Biologi Berbasis Mobile Learning terhadap Minat dan Kemampuan Berpikir Kreatif Siswa SMA Kota Masohi. Biodik, 6(1), 46-57.

Yanti, N. (2015). Keterampilan Guru dalam Pengelolaan Kelas. AlIshlah, 7(2), 347-360. 